JPCS

Peqguruang: Conference Series

eISSN: 2686-3472

Vol. 3 No. 2 Nov. 2021

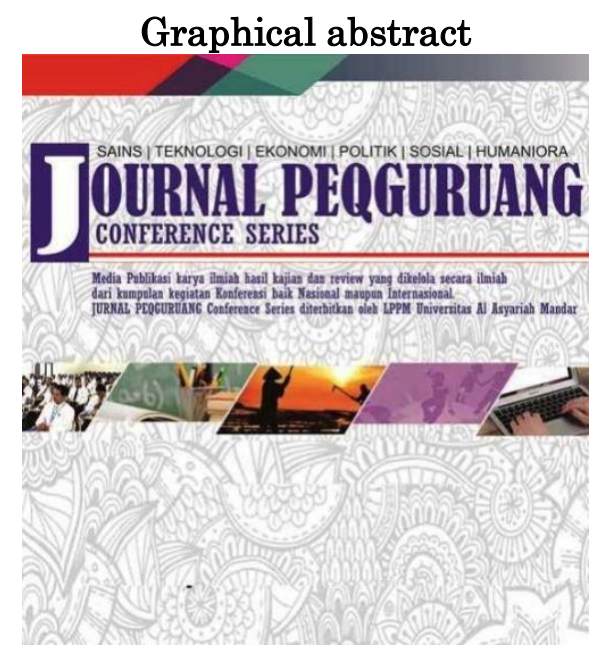

\title{
SISTEM DIGITALISASI ADMINISTRASI KEPENDUDUKAN PADA KANTOR DINAS KEPENDUDUKAN DAN PENCATATAN SIPIL KABUPATEN POLEWALI MANDAR
}

\author{
$1^{*}$ Muh.Irwandi, ${ }^{2}$ Rusli said, ${ }^{3}$ Basri \\ Universitas Al Asyariah Mandar \\ Corresponding author \\ irwandi@gmail.com
}

\begin{abstract}
Based on the Polewali Mandar Regency Regional Regulation concerning the Administration of Population and Civil Registration. will seek to obtain population data and accurate mapping as well as see the progress of the government in overcoming the problems that are being faced by the public. service procedures that still seem convoluted, delays in management, unaffordable costs. So we need an application system that aims to make it easier to manage new family cards and take care of birth certificates. In this research task, a Population Administration Digitization System was designed at the Office of Population and Civil Registration, Polewali Mandar Regency using Visual Studio Code, Xampp, PHP and MySQL based on Android and web. The final result of this research is that it will make it easier for people to manage new family cards and take care of birth certificates without going back and forth to the office and not waiting In Long Lines Using A Website-Based System.
\end{abstract}

Keywords: Service, Digitization, Population, Android

\begin{abstract}
Abstrak
Berdasarkan Peraturan Daerah Kabupaten Polewali Mandar Tentang Penyelenggaraan Administrasi Kependudukan dan Catatan Sipil. akan berupaya memperoleh data penduduk serta pemetaan yang akurat serta melihat kemajuan dari pemerintah untuk menanggulangi permasalah yang sedang dihadapi publik. prosedur pelayanan yang masih terkesan berbelit-belit, kelambatan dalam pengurusan, biaya yang tidak terjangkau. Sehingga di butuhkan system aplikasi yang bertujuan agar lebih mudah saat melakukan pengurusan kartu keluarga baru dan mengurus akta kelahiran. pada tugas penelitian ini dirancang Sistem Digitalisasi Administrasi Kependudukan Pada Kantor Dinas Kependudukan dan Pencatatan Sipil, Kabupaten Polewali Mandar menggunakan java script dan firebase berbasis Android dan web. Hasil Akhir dari penelitian ini yaitu akan mempermudah masyarakat dalam pengurusan kartu keluarga baru dan mengurus akta kelahiran tanpa mondar mandir kekantor dan tidak mengantri lama dengan menggunakan sistem berbasis website.
\end{abstract}

Kata kunci: Pelayanan, Digitalisasi, Penduduk, Android

Article history

DOI: https://dx.doi.org/10.35329/jp.v3i2.2400

Received : 23 Juli 2021 | Received in revised form : 29 Agustus 2021 | Accepted : 27 September 2021 


\section{PENDAHULUAN}

Negara Indonesia merupakan negara bekembang yang memiliki jumlah masyarakat yang tidak merata disetiap wilayah. Menyikapi masalah itu pemerintah berupaya mendapatkan data masyarakat melalui teknologi yang berlandaskan e-goverment guna menanggulangi permasalah pendataan kependudukan (Krisina, R., Subiyanto, S., \& Putra, A. 2013).

Dispendukcapil Kabupaten Polewali Mandar ialah lembaga pemerintah mengelolah persoalan adminiitrasi penduduk yang terdapat dikabupaten Polewali Mandar. Berdasarkan Peraturan Daerah Kabupaten Polewali Mandar Tentang Penyelenggaraan Administrasi Kependudukan dan Catatan Sipil. Alasan diterapkannyaa Perda tersebut pastinya akan berupaya memperoleh data penduduk serta pemetaan yang akurat serta melihat kemajuan dari pemerintah untuk menanggulangi permasalah yang sedang dihadapi publik.

Pada umumnya setiap masyarakat memerlukan pelayanan, bahkan secara ekstrim dapat dikatakan bahwa pelayanan tidak dapat dipisahkan dengan kehidupan masyarakat. Masyarakat setiap saat selalu menuntut pelayanan publik yang berkualitas dari birokrat, walaupun tuntutan tersebut sering tidak sesuai dengan harapan karena secara empiris pelayanan publik yang terjadi selama ini masih bercirikan: berbelit-belit, lambat, dan melelahkan. Kecenderungan seperti itu terjadi karena masyarakat masih diposisikan sebagai pihak "melayani" bukan yang dilayani. Hal ini menimbulkan dampak buruk terhadap perkembangan kualitas pelayanan yakni sering terlantarnya upaya peningkatan kualitas pelayanan dan kurang berkembangnya inovasi dalam pelayanan serta kurang terpacunya pemerintah daerah untuk memperbaiki kualitas pelayanan. ( Effendi Sandy Putra \& Elfi Tasrif, 2019 ).

Salah satu latar belakang dilaksanakannya Reformasi Birokrasi pada Sistem Administrasi Kependudukan adalah kualitas pelayanan publik yang belum memenuhi harapan masyarakat, dalam arti tingkat kepuasan masyarakat masih rendah, ditandai masih banyaknya keluhan-keluhan terhadap penyelenggara pelayanan publik, baik yang berkaitan dengan prosedur pelayanan yang masih terkesan berbelitbelit, kelambatan dalam pengurusan, biaya yang tidak terjangkau maupun sikap petugas pelayanan yang tidak mencerminkan sikap sebagai abdi masyarakat. ( Suryani Irma \& Jamaluddin,2016).

Penelitian terkait sebagaimana dilakukan oleh Wike Pertiwi dan Fika Nurhikmah tahun 2018. Telah melakukan penelitian tentangPengaruh Perubahan Sistem Digitalisasi Terhadap Kinerja Karyawan. Penelitian ini dilakukan untuk mengetahui Pengaruh Perubahan Sistem Digitalisasi Terhadap Kinerja Karyawan Pada PT. Bank Tabungan Pensiunan Nasional Syariah Cabang Majalengka motode yang digunakan dalam penelitian ini adalah penelitian kuantitatif, teknik pengumpulan data dengan penyebaran kuesioner, wawancara dan observasi kepada seluruh karyawan BTPN syariah wilayah Majalengka dan Cirebon sehingga mendapatkan informasi-informasi yang dibutuhkan untuk melanjutkan penelitian (Pertiwi, W., \& Nurhikmah, F. 2018)

Penelitian terkait sebagaimana dilakukan oleh Riyadi, A. S., Retnadi, E., \& Supriatna, A. D. tahun 2012. Telah Melakukan penelitian tentang Perancangan Digitalisasi Pelayanan Administrasi Akademik Jurusan Teknik Elektronika Berbasis Android. Penelitian ini dilakukan untuk meningkatkan aspek layanan administrasi jurusan dan memberikan kepuasan terhadap mahasiswa di perguruan tinggi khususnya jurusan Teknik Elektronika Fakultas Teknik Universitas Negeri Padang (Riyadi, A. S., Retnadi, E., \& Supriatna, A. D. 2012).

Penelitian terkait sebagaimana dilakukan oleh Welim, Y. Y., \& Sakti, A. R. tahun 2016. penelitiannya yang berjudul tentang Rancang Bangun Sistem Informasi Administrasi Pengelolaan Dana Masjid Pada Yayasan AlMuhajiriin. Penelitian ini dilakukan untuk mengetahui pelayanan adminsitrasi kependudukan terutama Pencatatan atas pelaporan peristiwa kependudukan dalam hal ini adalah administrasi keterangan pindah dan pencatatan sipil berupa pencatatan kelahiran dalam hal ini adalah penerbitan surat keterangan kelahiran sebagai dasar pembuatan akte kelahiran Welim, Y. Y., \& Sakti, A. R. 2016).

Penelitian terkait sebagaimana dilakukan oleh Yayat Rukayat. tahun 2017, telah melakukan penelitian Kualitas Pelayanan Publik Bidang Administrasi Kependudukan Di Kecamatan Pasirjambu. Penelitian ini adalah penelitian deskriptif dengan menggunakan pendekatan kualitatif untuk mengetahui kualitas pelayanan publik bidang administrasi kependudukan diKecamatan Pasirjambu. Teknik analisis data yang digunakan adalah model interaktif.Hasil penelitian menunjukkan bahwa kualitas pelayanan publik bidang administrasikependudukan di Kecamatan Pasirjambu dilihat dari aspek fasilitas fisik, kehandalan,daya tanggap, jaminan, empati yaitu bagian Pelayanan Umum di Kecamatan Pasirjambubelum memenuhi fasilitas pelayanan yang memadai untuk memberikan pelayanankepada masyarakat (Yayat, R. 2017).

Penelitian terkait sebagaimana dilakukan oleh Paryanta, dkk. tahun 2017, telah melakukan penelitian Sistem Informasi Administrasi Kependudukan Berbasis Web Desa Sawahan. Administrasi Penduduk Sistem Informasi Pedesaan Situs Berbasis Desa Sawahan dibangun dengan menggunakan studi kasus deskriptif Desa Sawahan. Analisis teknik kelemahan dalam sistem yang diteliti dengan menggunakan analisis PIECES (Performance, Information, Economy, cotrol, Efficiency and Service). Untuk teknik pengembangan sistem menggunakan metode waterfall, sedangkan untuk menggambarkan arus data menggunakan DFD (Data Flow Diagram). Software yang digunakan untuk membangun sistem ini adalah PHP (Hyertext Preprocessor) dan XAMPP sebagai koneksi ke database MySQL (Paryanta, dkk. tahun 2017).

Penelitian terkait sebagaimana dilakukan oleh Basri, B., Said, R., \& Fitriani, N. tahun 2019, telah melakukan penelitian tentang Perangkingan Peserta Didik Menggunakan Sistem Penunjang Keputusan 
Berbasis Aplikasi dengan Pendekatan Metode Fuzzy Analytical Hierarchy Process (FAHP), Penelitian ini bertujuan untuk mengimplementasikan Metode Fuzzy Analytical Hierarchy Process dalam Aplikasi pendukung keputusan yang berfungsi untuk menentukan rangking peserta didik. Kegiatan penelitian ini dilakukan di MTs DDI Manding. Dalam menentukan perankingan digunakan tiga kriteria yaitu nilai kompetensi pengetahuan, nilai kompetensi, sikap, dan nilai kompetensi keterampilan. Hasil penelitian menunjukkan bahwa sistem yang dirancang dapat memberikan rekomendasi perangkingan yang sesuai dan lebih cepat serta lebih dinamis dibanding cara manual yang saat ini banyak diterapkan. Selain itu hasil observasi menunjukkkan bahwa penggunaan Aplikasi dengan pendekatan Sistem Penunjang Keputusan menggunakan perhitungan Fuzzy Analytical Hierarchy Process memberikan kemudahan kepada pihakwali kelas dalam mementukan rangking peserta didik (Basri, B., Said, R., \& Fitriani, N, 2019).

Penelitian terkait sebagaimana dilakukan oleh Gadis, F., Said, M. R., \& Sofyan, E. tahun 2020. telah melakukan penelitian tentang Sistem Informasi Pemetaan Pembuatan Sarung Sutera Mandar Berbasis Web Pada Perkampungan Tenun Desa Tammangalle Tujuan dari penelitian ini adalah untuk merancang dan membangun aplikasi sistem informasi pemetaan pembuatan sarung sutera berbasis web di desa Tammangalle Kabupeten Balanipa dan menguji kelayakan aplikasi system informasi pemetaan pembuatan sarung sutera berbasis web di desa Tammangalle Kabupeten Balanipa. Metode yang digunakan yaitu dengan metode pengamatan langsung, wawancara dan kepustakaan. Hasil penelitian ini adalah adanya suatu aplikasi system informasi pemetaan pembuatan sarung sutera di desa Tammangalle Kecamatan balanipa yang dapat memberikan informasi yang efektif kepada pengunjung Desa Tammangalle yang ingin mengetahui corak-corak sarung sutra (Gadis, F., Said, M. R., \& Sofyan, E. tahun 2020).

Adapun tujuan penelitian ini ialah menghasilkan Adapun perbedaan penelitian dari penelitian sebelumnya adalah dalam penelitian ini akan menghasilkan Sistem Digitalisasi Administrasi KependudukanPada Kantor Dinas Kependudukan dan Pencatatan Sipil, KabupatenPolewali Mandar" akan mempermudah masyarakat dalam pengurusan kartu keluarga baru dan mengurus akta kelahiran tanpa mondar mandir kekantor dan tidak mengantri lama dengan menggunakan sistem berbasis website.

\section{METODE PENELITIAN}

\section{Bahan Penelitian}

Dalam proses penyusunan tugas akhir ini, bahan penelitian yang di perlukan dalam perancangan sistem ini yakni berupa data dan file serta berkas dan hal-hal yang mungkin diperlukan dalam perancangan sistem ini.
Berdasarkan kerangka sistem yang telah dibuat, penjelasan dari tahapan Menjelaskan tujuan yang ingin dicapai. Struktur sistem berisi input dan output dari proses penelitian yang dilakukan. Kerangka sistem yang dimaksud ditunjukkan pada gambar 1 .

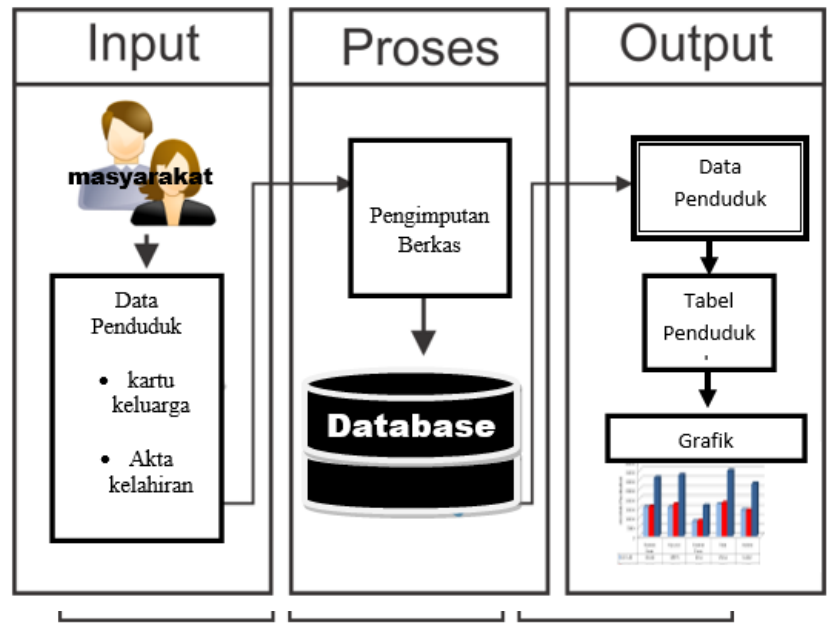

Gambar 1. Kerangka Sistem

\section{HASIL DAN PEMBAHASAN}

\section{Hasil perancangan}

Penelitian ini telah berhasil membangun suatu sistem digitalisasi administrasi kependudukan pada kantor dinas kependudukan pencatatan sipil kabupaten polewali mandar, dimana sistem ini akan mempermudah masyarakat dalam pengurusan kartu keluarga baru dan mengurus akta kelahiran tanpa mondar mandir kekantor dan tidak mengantri lama dengan menggunakan sistem ini, adapun Hasil Pengembangan Sistem Program sebagai berikut:

\section{Hasil Pengembangan Sistem}

a. Form Menu dashboard user

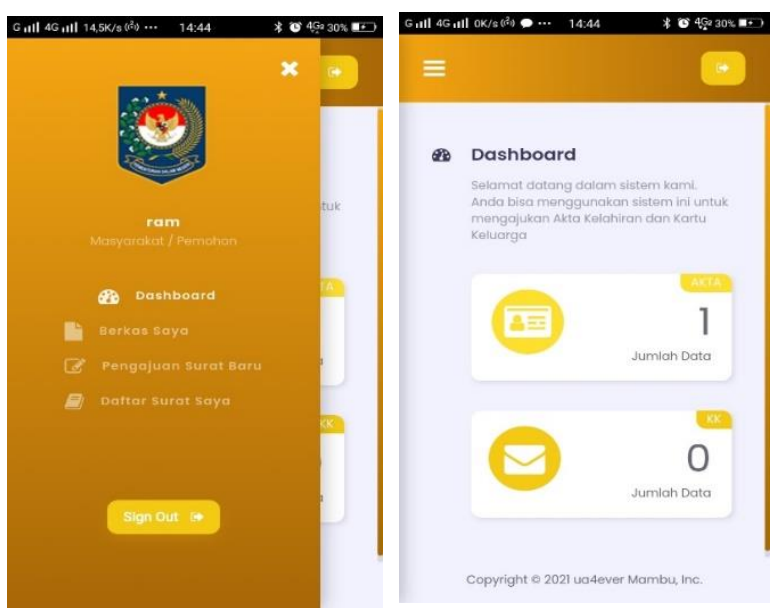

Gambar 2. tampilan halaman Dashboard

Kerangka sistem 
Form ini adalah tampilan yang digunakan pengguna untuk menampilkan fitur yang ada pada sistem seperti dashboard, berkas saya, pengajuan surat baru, daftar surat saya dan sign out.

\section{b. Form Berkas saya.}

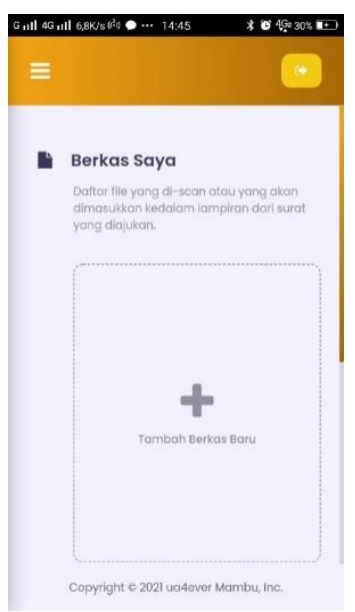

Gambar 3. Form Berkas saya

Form ini merupakn form yang digunakan untuk memasukkan file yang di-scan atau yang akan dimasukkan kedalam lampiran dari surat yang diajukan.

\section{c. Form pengajuan surat baru}
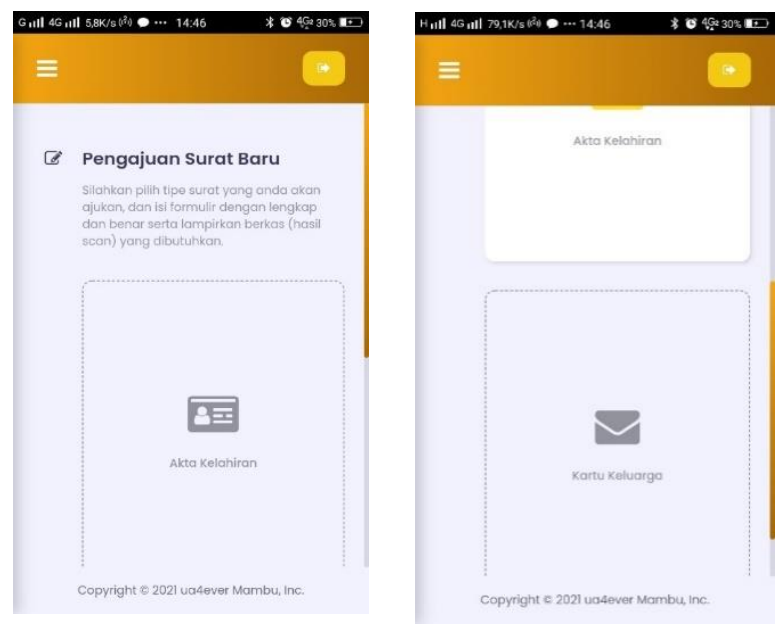

Gambar 4. Form pengajuan surat baru

Form ini merupakan tampilan yang digunakan untuk memilih tipe surat yang anda akan ajukan.

\section{d. Form daftar surat saya}

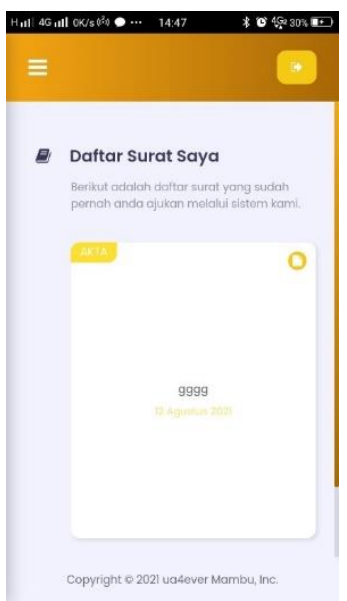

Gambar 5. Form daftar surat saya

Form ini merupakan daftar surat yang sudah pernah di ajukan melalui sistem.

\section{e. Form login}

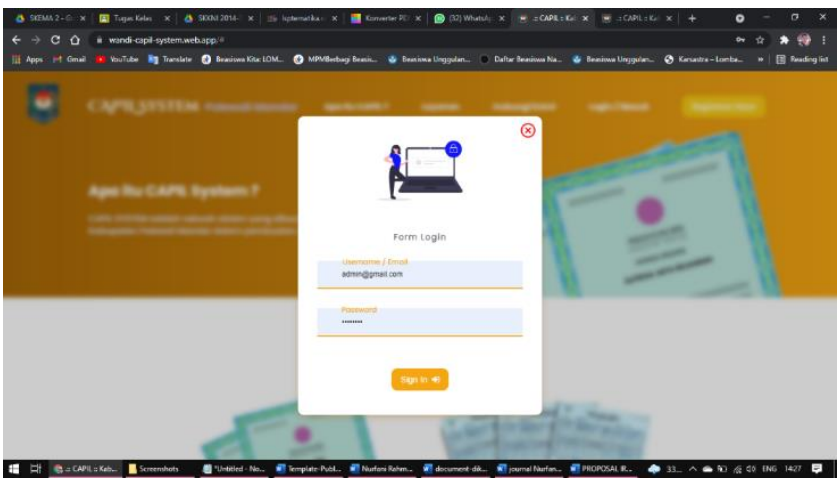

Gambar 6. Form login

Jika form login telah terisi dan ter autentikasi dengan benar maka sistem pada menu utama admin akan tampil, dan jika tidak valid maka password dan Username akan kosong dan login tidak berhasil.

\section{f. Form dashboard admin}

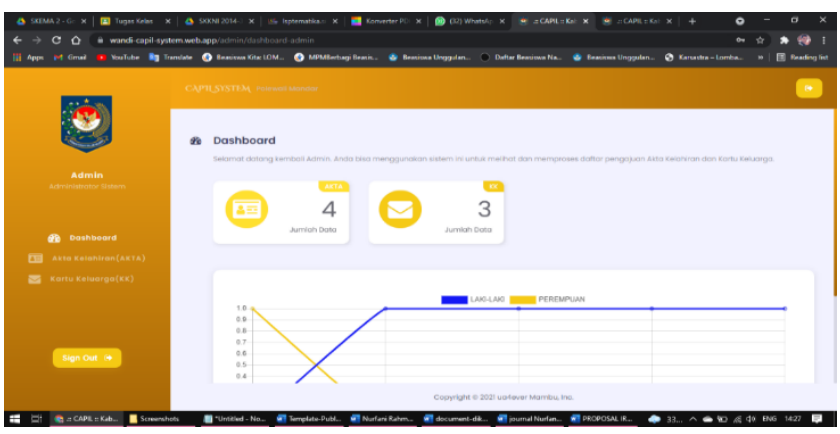

Gambar 7. Form dashboard admin 
Form ini merupakan form yang digunakan pada sistem ini untuk melihat dan memproses daftar pengajuan Akta Kelahiran dan Kartu Keluarga.

\section{g. Form Akta Kelahiran}

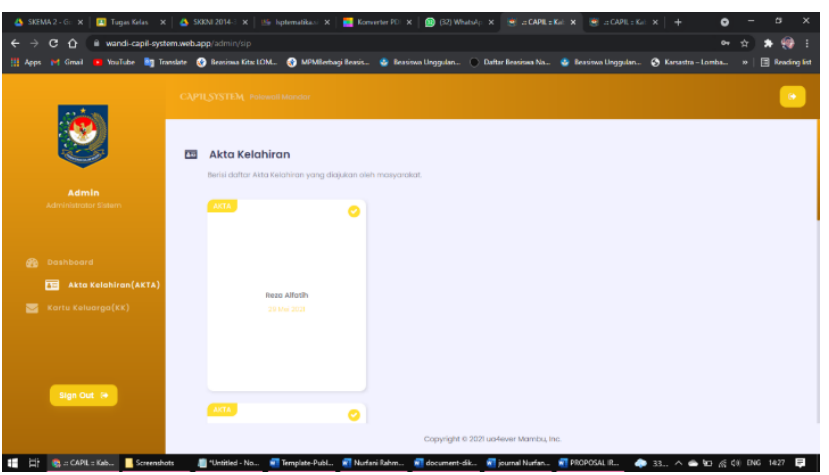

Gambar 8. Form admin

Form ini merupakan form yang digunakan pada sistem ini untuk melihat akta kelahiran

\section{Uji Coba Sistem dan Program}

Selama pengujian, sistem menggunakan pendekatan pengujian yang menggunakan pengujian Black box dan simulasi aplikasi. Hasil pengujian menggunakan black box test adalah sebagai berikut:

Tabel 1. Hasil Pengujian blackbox admin

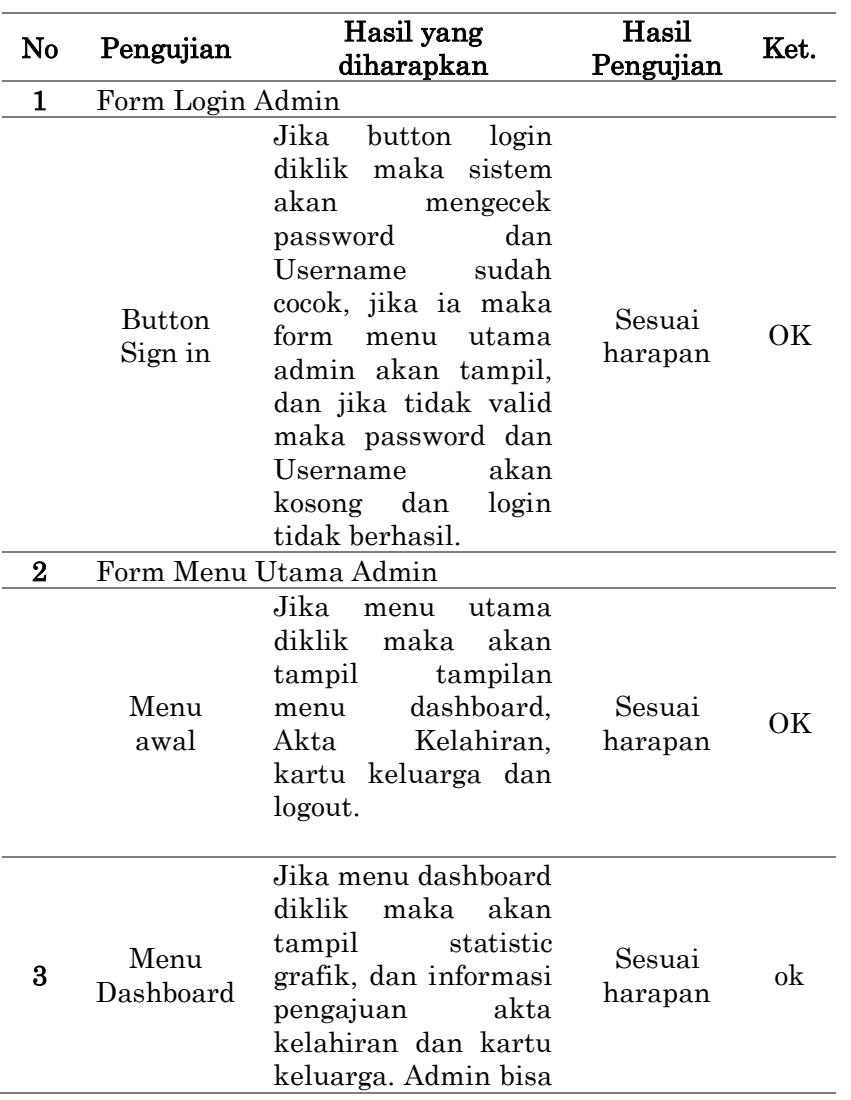

\begin{tabular}{|c|c|c|c|c|}
\hline & & $\begin{array}{l}\text { menggunakan sistem } \\
\text { ini untuk melihat dan } \\
\text { memproses daftar } \\
\text { pengajuan Akta } \\
\text { Kelahiran dan Kartu } \\
\text { Keluarga. }\end{array}$ & & \\
\hline 4 & $\begin{array}{l}\text { Menu } \\
\text { AKTA }\end{array}$ & $\begin{array}{lr}\text { Jika menu akta di } \\
\text { klik maka } & \text { berisi } \\
\text { daftar } & \text { Akta } \\
\text { Kelahiran } & \text { yang } \\
\text { diajukan } & \text { oleh } \\
\text { masyarakat, admin } \\
\text { dapat melihat dan } \\
\text { memproses } & \\
\text { pengajuan } & \text { Akta } \\
\text { kelahiran. } & \end{array}$ & $\begin{array}{c}\text { Sesuai } \\
\text { harapan }\end{array}$ & ok \\
\hline 5 & Menu KK & $\begin{array}{lr}\text { Jika menu akta di } \\
\text { klik maka } & \text { berisi } \\
\text { daftar } & \text { Kartu } \\
\text { keluarga } & \text { yang } \\
\text { diajukan } & \text { oleh } \\
\text { masyarakat, admin } \\
\text { dapat melihat dan } \\
\text { memproses } & \\
\text { pengajuan } & \text { Akta } \\
\text { kelahiran. } & \end{array}$ & $\begin{array}{c}\text { Sesuai } \\
\text { harapan }\end{array}$ & ok \\
\hline 6 & $\begin{array}{l}\text { Tombol } \\
\text { Logout }\end{array}$ & $\begin{array}{l}\text { Jika diklik akan } \\
\text { kembali ke halaman } \\
\text { login admin }\end{array}$ & $\begin{array}{c}\text { Sesuai } \\
\text { harapan }\end{array}$ & ok \\
\hline
\end{tabular}

Tabel 2. Hasil Pengujian blackbox user

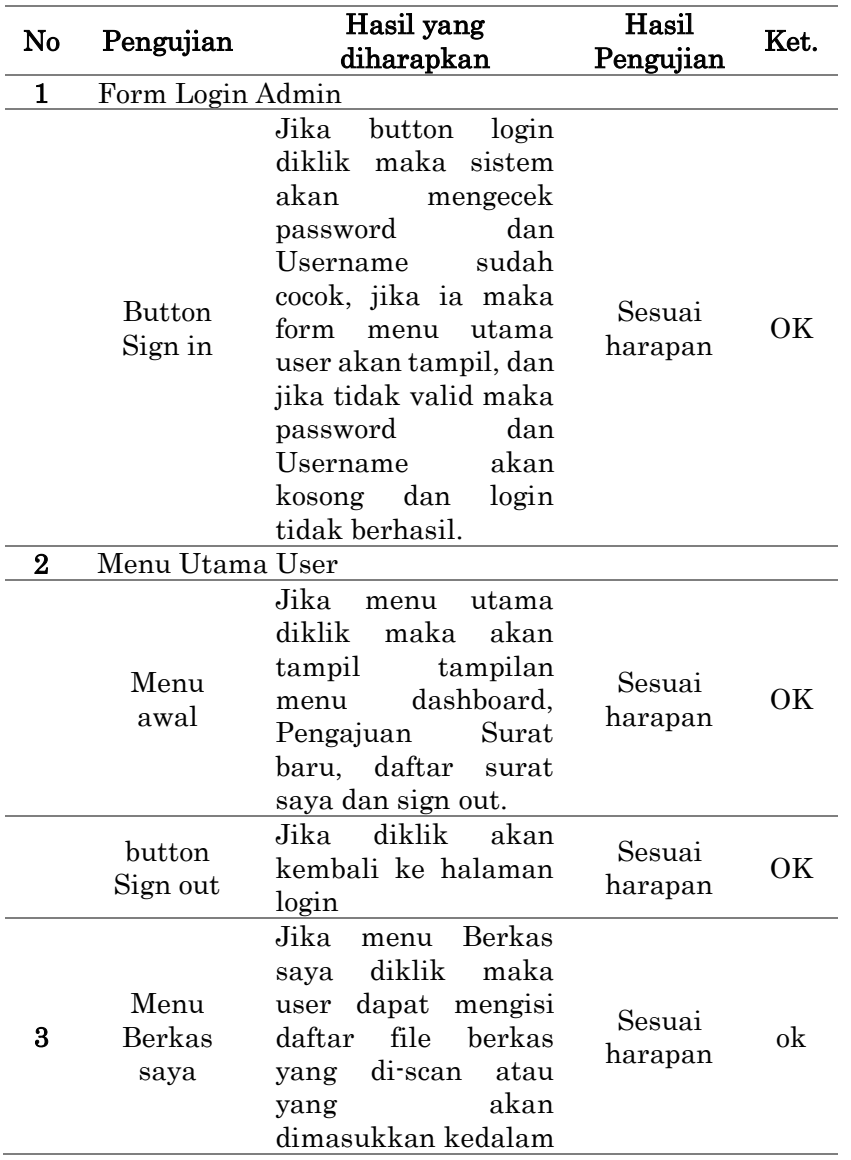




\begin{tabular}{|c|c|c|c|c|}
\hline & & $\begin{array}{l}\text { lampiran dari surat } \\
\text { yang diajukan. }\end{array}$ & & \\
\hline 4 & $\begin{array}{c}\text { Menu } \\
\text { Dashboard }\end{array}$ & $\begin{array}{l}\text { Jika menu dashboard } \\
\text { diklik maka user } \\
\text { dapat melihat jumlah } \\
\text { data AKTA dan } \\
\text { jumlah data KK pada } \\
\text { sistem. }\end{array}$ & $\begin{array}{c}\text { Sesuai } \\
\text { harapan }\end{array}$ & ok \\
\hline 5 & $\begin{array}{c}\text { Menu } \\
\text { Pengajuan } \\
\text { surat baru }\end{array}$ & $\begin{array}{l}\text { Jika Menu } \\
\text { Pengajuan surat baru } \\
\text { di klik maka akan } \\
\text { ada } 2 \text { pilihan, user } \\
\text { memilih tipe surat } \\
\text { yang akan di ajukan, } \\
\text { dan isi formulir } \\
\text { dengan lengkap dan } \\
\text { benar serta } \\
\text { lampirkan berkas } \\
\text { (hasil scan) yang } \\
\text { dibutuhkan }\end{array}$ & $\begin{array}{c}\text { Sesuai } \\
\text { harapan }\end{array}$ & ok \\
\hline 6 & $\begin{array}{c}\text { Menu } \\
\text { Daftar } \\
\text { surat saya }\end{array}$ & $\begin{array}{l}\text { Jika Daftar surat } \\
\text { saya maka yang akan } \\
\text { tampil adalah daftar } \\
\text { surat yang sudah } \\
\text { pernah user ajukan } \\
\text { melalui sistem kami. }\end{array}$ & $\begin{array}{c}\text { Sesuai } \\
\text { harapan }\end{array}$ & ok \\
\hline 7 & $\begin{array}{l}\text { Tombol } \\
\text { sign out }\end{array}$ & $\begin{array}{l}\text { Jika diklik akan } \\
\text { kembali ke halaman } \\
\text { login user. }\end{array}$ & $\begin{array}{c}\text { Sesuai } \\
\text { harapan }\end{array}$ & ok \\
\hline
\end{tabular}

Berdasarkan table dari hasil pengujian Black box diatas dapat disimpulkan bahwa program aplikasi yang dirancang adalah valid. Dalam hal ini, program dideklarasikan tanpa kesalahan.

\section{SIMPULAN}

Berdasar pada hasil Penelitian dilakukan sejak awal proses pengujian sistem terhadap aplikasi yang dirancang yaitu Sistem Digitalisasi Administrasi Kependudukan pada kantor Dinas Kependudukan dan Pencatatan Sipil Kabupaten Polewali Mandar berhasil sesuai dengan tujuan awal yaitu dengan adanya alat bantu untuk mempermudah masyarakat dalam pengurusan kartu keluarga baru dan mengurus akta kelahiran tanpa mondar mandir kekantor dan tidak mengantri lama dengan menggunakan sistem yang lama.

Saran yang dapat disampaikan dalam penelitian ini yaitu diperlukan kepada segenap pihak terkait dalam menyesuaikan diri dari sistem informasi lama menuju informasi yang diusulkan.

Demikian Kesimpulan dan Saran penulis semoga hal tersebut dapat di jadikan sebagai bahan masukan bagi mahasiswa-mahasiswi terkhusus kepada penulis.

\section{DAFTAR PUSTAKA}

Krisina, R., Subiyanto, S., \& Putra, A. (2013). Aplikasi Persebaran Alumni Teknik Geodesi Universitas Diponegoro Berbasis Webgis. Geodesi Undip, 2(Sistem Informasi Geografis), 240-252.

Effendi, S. P., \& Tasrif, E. (2019). Perancangan Digitalisasi Pelayanan Administrasi Akademik
Jurusan Teknik Elektronika Berbasis Android. JVOTEKNIKA:Jurnal Vokasional Teknik Elektronika Dan Informatika, 7(2).

Suryani, I. \& J. (2016). Pelayanan Administrasi Kependudukan Pada Kantor Kecamatan Pattallassang Kabupaten Gowa. Jurnal Office, 2(2), 134-142.

ojs.unm.ac.id/index.php/jo/article/view/2918

Pertiwi, W., \& Nurhikmah, F. (2018). Pengaruh Perubahan Sistem Digitalisasi Terhadap Kinerja Karyawan. Seminar Nasional Multidisiplin 2018, September,

$187-191$. http://ejournal.unwaha.ac.id/index.php/snami/articl e/view/288/244.

Riyadi, A. S., Retnadi, E., \& Supriatna, A. D. (2012). Perancangan sistem informasi berbasis website subsistem guru di sekolah pesantren persatuan islam 99 rancabango. Jurnal Algoritma, 9(2), 327337.

Welim, Y. Y., \& Sakti, A. R. (2016). Rancang Bangun Sistem Informasi Administrasi Pengelolaan Dana Masjid Pada Yayasan Al-Muhajiriin, Tangerang. Simetris : Jurnal Teknik Mesin, Elektro Dan Ilmu Komputer, 7(1), 29. https://doi.org/10.24176/simet.v7i1.485

Yayat, R. (2017). Kualitas Pelayanan Publik Bidang Administrasi Kependudukan Di Kecamatan Gamping. Jurnal Ilmiah Magister Ilmu Administrasi (JIMIA), 2, 56-65. http://eprints.uny.ac.id/17523/1/SKRIPSI

FULL.pdf(Krisina et al., 2013; Sasmito, 2017; Yayat, 2017).

Paryanta,S.,\&Susilowati,

D. (2017).SistemInformasiAdministrasiKependuduka nBerbasis Web DesaSawahan. IJSE-Indones. J. Softw. Eng, 3(2), 77-81

Basri, B., Said, R., \& Fitriani, N. (2019, November). Perangkingan Peserta Didik Menggunakan Sistem Penunjang Keputusan Berbasis Aplikasi dengan Pendekatan Metode Fuzzy Analytical Hierarchy Process (FAHP). In Journal Peqguruang: Conference Series (Vol. 1, No. 2, pp. 139-144).

Gadis, F., Said, M. R., \& Sofyan, E. (2020, May). Sistem Informasi Pemetaan Pembuatan Sarung Sutera Mandar Berbasis Web Pada Perkampungan Tenun Desa Tammangalle. In Journal Peqguruang: Conference Series (Vol. 2, No. 1). 